\title{
FGFR2 Gene Mutation Negative
}

National Cancer Institute

\section{Source}

National Cancer Institute. FGFR2 Gene Mutation Negative. NCI Thesaurus. Code C160363.

A genetic finding indicating that FGFR2 gene mutations have not been detected in a sample. 